\title{
Prevalence and Determinants of High Blood Pressure among Adolescents: A School based Study in Rural Area of Hooghly District, West Bengal
}

\author{
Malay Kumar Das ${ }^{1}$, Rabindranath Sinha ${ }^{2}$, Aparajita Dasgupta ${ }^{3}$, Sudipta Das ${ }^{4}$ \\ ${ }^{1}$ Demonstrator, Dept. of Community Medicine, Murshidabad Medical College, \\ ${ }^{2}$ Professor, Department of M.C.H, AIIH \& PH, Kolkata. \\ ${ }^{3}$ Ex Prof. and Head of the Dept. of P.S.M, AIIH \& PH, Kolkata. \\ ${ }^{4}$ Demonstrator, Dept. of Community Medicine, Medical College, Kolkata.
}

Corresponding Author: Malay Kumar Das

\begin{abstract}
Introduction: The World Health Organization has already warned of increasing noncommunicable diseases among adolescents as a major public health problem. The importance of this age group also lies in the fact that many serious diseases in adulthood have their roots in adolescence.
\end{abstract}

Method: A pre-designed and pre-tested questionnaire was used in class-room setting to collect information from students regarding presence of risk factors of non-communicable diseases. The respondents were also subjected to anthropometric measurements and blood pressure examination using standard operating procedures.

Results: A total of 761 students of class VI-XII participated in the study of which $61.4 \%$ were boys and rests were girls. High blood pressure among boys and girls were $19.9 \%$ and $22.1 \%$ were respectively. In Bivariate analysis age $>15$ years (median) $(\mathrm{OR}=2.11)$, fast food intake $(>3$ times/week) $(\mathrm{OR}=1.66)$, Alcohol consumption $(\mathrm{OR}=2.22)$, less physical activity $(\mathrm{OR}=1.54)$, increased body mass index $(\mathrm{OR}=2.53)$, significantly associated with high blood pressure. In Multivariate analysis age (AOR= 2.25), fast food intake $(\mathrm{AOR}=1.50)$, Alcohol consumption $(\mathrm{OR}=2.23)$, less physical activity $(\mathrm{AOR}=1.71)$, increased body mass index $(A O R=2.42)$ remains significant predictor.

Conclusion: Detecting the risk factors of high blood pressure prevalent in the population is of utmost importance to achieve a healthy population. Formulation and dissemination of need--based, culturally acceptable and ageappropriate scientific messages for school students should be conducted more proactively.

Key Words: Adolescents, Blood pressure, Risk factor, Rural school.

\section{INTRODUCTION}

Increasing trends of noncommunicable diseases is a worldwide phenomenon. India is experiencing a rapid health transition with a rising burden of non-communicable diseases.

The World Health Organization has already warned of increasing noncommunicable diseases among adolescents as a major public health problem. The importance of this age group also lies in the fact that many serious diseases in adulthood have their roots in adolescence.

Interventions must start in childhood because this is the time when the disease processes start and when life style habits are formed. India has a huge adolescent population with various social and health inequalities. To reduce the development of non-communicable diseases in adulthood, the ideal time of intervention is during adolescence because young children are amenable to correction.

The co-education higher-secondary school (class V-XII) has over thousands of students of different demographic backgrounds. This is the best way to study 
prevalence and determinants of high blood pressure among adolescents. With this concept a study was conducted to assess the risk factors of non communicable diseases among school children in a rural setting of West Bengal. Since more than $71 \%$ of the India population live in the villages and many of the deadly risk factors which once belonged solely to the urban population are rapidly percolating into the rural population the prevalence of non-communicable disease is rapidly increasing by leaps and bounds in the rural population.

\section{MATERIAL AND METHODS}

Among the rural block of Hooghly district Tarakeswar was chosen due to its proximity to the megacity of Kolkata which influences the lifestyle pattern and other behavioural characteristics of the people residing in the area. Among five higher secondary co-education schools under Tarakeswar block, Ramnagar Noot Behari Pal Chowdhury High School has been selected for the study. The school caters highest number of students among the five. The present school- based cross sectional study was conducted among students of class VI-XII of academic year 2014-15 (May 2014 to April 2015). A total of 761 students in the age group of 10-18 years were participated in the study of which 61.4\% were boys and rests were girls.

Ethical consideration was taken from the Institutional Ethics Committee of All India Institute of Hygiene and Public Health prior to the study. After taking permission from school authority and consent from each participant; they were explained the purpose of the study. All willing students present in the class/section on the day of questionnaire data collection were also subjected to anthropometric measurements and blood pressure examination using standard operating procedures. Information collected was recorded in a predesigned schedule. Any participant having any physical disabilities and congenital anomalies were excluded from the study.
The questionnaire was designed as a booklet in Bengali language with instructions based on WHO STEPS methodology ${ }^{[1]}$ and WHO Global Schoolbased Student Survey [2] with some modification to use in class-room setting to collect information from students regarding the presence of risk factors of noncommunicable diseases. Face validity of each item and content validity of each domain was ascertained by a group of experts in AIIIH and PH, Kolkata. Prior to the study, the questionnaire was pretested on students of a different school of the same block.

Age, height and weight were recorded in year, centimetre and kilogram respectively. BMI was categorized by $\mathrm{WHO}$ $\mathrm{Z}$ score ${ }^{[3]}$. BP was categorized by National High Blood Pressure Education Program Working Group on High Blood Pressure in Children and Adolescents. Guidelines for age 10-17 years ${ }^{[4]}$, JNC VII for age 18 years [5] Age was verified from school record book. Data were entered into a spread sheet and exported to Statistical Package for the Social Science ${ }^{\circledR}$ (SPSS) for Windows, version 16.0 software for analysis.

\section{RESULTS}

Table 1: Sex-wise distribution of students according to age group $(n=761)$

\begin{tabular}{|l|l|l|l|}
\hline $\begin{array}{l}\text { Age group } \\
\text { (years) }\end{array}$ & $\begin{array}{l}\text { Boys } \\
\text { No (\%) }\end{array}$ & $\begin{array}{l}\text { Girls } \\
\text { No (\%) }\end{array}$ & $\begin{array}{l}\text { Total } \\
\text { No (\%) }\end{array}$ \\
\hline $10-12$ & $142(30.4)$ & $94(32)$ & $236(31)$ \\
\hline $13-15$ & $215(46)$ & $123(41.8)$ & $338(44.4)$ \\
\hline $16-18$ & $110(23.6)$ & $77(26.2)$ & $187(24.6)$ \\
\hline Total & $\mathbf{4 6 7 ( 1 0 0 )}$ & $\mathbf{2 9 4 ( 1 0 0 )}$ & $\mathbf{7 6 1 ( 1 0 0 )}$ \\
\hline
\end{tabular}

Students in the age group of 10-12 years, 13-15years and 16-18 years were $31 \%, 44.4 \%$ and $24.6 \%$ respectively.

Table 2: Sex-wise analysis of Blood pressure $(n=761)$

\begin{tabular}{|l|l|l|l|}
\hline Blood pressure(category) & $\begin{array}{l}\text { Boys } \\
\text { No (\%) }\end{array}$ & $\begin{array}{l}\text { Girls } \\
\text { No (\%) }\end{array}$ & $\begin{array}{l}\text { Total } \\
\text { No (\%) }\end{array}$ \\
\hline Normal & $374(80.1)$ & $229(77.9)$ & $603(79.2)$ \\
\hline Pre hypertension & $67(14.3)$ & $37(12.6)$ & $104(13.7)$ \\
\hline Hypertension & $26(5.6)$ & $28(9.5)$ & $54(7.1)$ \\
\hline Total & $\mathbf{4 6 7 ( 1 0 0 )}$ & $\mathbf{2 9 4 ( 1 0 0 )}$ & $\mathbf{7 6 1 ( 1 0 0 )}$ \\
\hline
\end{tabular}

*no student had history of medication/treatment for hypertension.

About one fifth of students (20.8\%) were found to have high blood pressure and $7.1 \%$ of students were suffering from hypertension. High blood pressure among 
Malay Kumar Das et.al. Prevalence and determinants of high blood pressure among adolescents: a school based study in rural area of Hooghly district, West Bengal.

boys and girls were $19.9 \%$ and $22.1 \%$ were respectively.

Table 3: Distribution of blood pressure according to age group (n=761)
\begin{tabular}{|l|l|l|l|}
\hline Age group (years) & $\begin{array}{l}\text { Normal } \\
\text { No (\%) }\end{array}$ & $\begin{array}{l}\text { Pre hypertension } \\
\text { No }(\%)\end{array}$ & $\begin{array}{l}\text { Hypertension } \\
\text { No (\%) }\end{array}$ \\
\hline $10-12$ & $220(93.2)$ & $7(3)$ & $9(3.8)$ \\
\hline $13-15$ & $250(74)$ & $56(16.6)$ & $32(9.5)$ \\
\hline $16-18$ & $133(71.1)$ & $41(21.9)$ & $13(7)$ \\
\hline
\end{tabular}

Age group-wise 3.8\%, 9.5\% and 7\% students of 10-12 years, $13-15$ years and 16-18 years were hypertensive.

Table 4: Distribution of risk factors for non-communicable diseases according to sex

\begin{tabular}{|l|l|l|l|}
\hline $\begin{array}{l}\text { Risk factors of } \\
\text { non-communicable diseases }\end{array}$ & $\begin{array}{l}\text { Boys (n=467) } \\
\text { No (\%) }\end{array}$ & $\begin{array}{l}\text { Girls (n=294) } \\
\text { No (\%) }\end{array}$ & $\begin{array}{l}\text { Total (n=761) } \\
\text { No (\%) }\end{array}$ \\
\hline Fruits and vegetables $<5$ times/week & $92(19.7)$ & $49(16.7)$ & $141(18.5)$ \\
\hline Fast food >3 times/week & $164(35.1)$ & $93(31.6)$ & $257(33.8)$ \\
\hline Extra salt intake in food & $257(55)$ & $159(54.1)$ & $416(54.7)$ \\
\hline Tobacco use in the past 30 days & $106(22.7)$ & $3(1)$ & $109(14.3)$ \\
\hline Alcohol consumption in the past 30 days & $46(9.9)$ & $2(0.7)$ & $48(6.3)$ \\
\hline Less physical activity & $101(21.6)$ & $161(54.8)$ & $262(34.4)$ \\
\hline Family history of non-communicable diseases & $161(34.5)$ & $102(34.7)$ & $263(34.6)$ \\
\hline Overweight and obesity & $59(12.6)$ & $34(11.6)$ & $93(12.2)$ \\
\hline Hypertension and pre hypertension & $93(19.9)$ & $65(22.1)$ & $158(20.8)$ \\
\hline
\end{tabular}

Most common risk factor was 'intake of extra salt with food' (54.7\%), followed by fast food intake $>3$ times/week (33.8\%).

\begin{tabular}{|c|c|c|}
\hline \multirow[t]{2}{*}{ Variables (referent) } & \multicolumn{2}{|c|}{ High blood pressure } \\
\hline & $\begin{array}{l}\text { O.R. } \\
\text { (95 \% C.I.) }\end{array}$ & $\begin{array}{l}\text { A.O.R. } \\
\text { (95 \% C.I.) }\end{array}$ \\
\hline Age $(\leq 15$ years $)$ & $\begin{array}{l}2.11 * * * \\
(1.48-3.02)\end{array}$ & $\begin{array}{l}2.25 * * * \\
(1.52-3.33)\end{array}$ \\
\hline Sex(Girls) & $\begin{array}{l}0.88 \\
(0.61-1.25)\end{array}$ & $\begin{array}{l}1 \\
(0.66-1.51)\end{array}$ \\
\hline Fruits and vegetables ( $\geq 5$ times/week) & $\begin{array}{l}0.79 \\
(0.49-1.27)\end{array}$ & $\begin{array}{l}0.74 \\
(0.45-1.23)\end{array}$ \\
\hline Fast food( $\leq 3$ times/week) & $\begin{array}{l}1.66 * * \\
(1.16-2.37)\end{array}$ & $\begin{array}{l}1.50^{*} \\
(1.03-2.19)\end{array}$ \\
\hline Extra salt intake in food(No) & $\begin{array}{l}0.87 \\
(0.61-1.23)\end{array}$ & $\begin{array}{l}0.92 \\
(0.64-1.33)\end{array}$ \\
\hline Tobacco use(No) & $\begin{array}{l}0.90 \\
(0.54-1.50)\end{array}$ & $\begin{array}{l}0.72 \\
(0.38-1.36)\end{array}$ \\
\hline Alcohol consumption(No) & $\begin{array}{l}2.22 * \\
(1.20-4.13)\end{array}$ & $\begin{array}{l}2.23^{*} \\
(1.04-4.77)\end{array}$ \\
\hline Physical activity (Active) & $\begin{array}{l}1.54 * \\
(1.08-2.21))\end{array}$ & $\begin{array}{l}1.71^{*} \\
(1.13-2.58)\end{array}$ \\
\hline Family history of non-communicable diseases(No) & $\begin{array}{l}1.01 \\
(0.70-1.47)\end{array}$ & $\begin{array}{l}1.14 \\
(0.77-1.68)\end{array}$ \\
\hline Increased body mass index (No) & $\begin{array}{l}2.53 * * * \\
(1.59-4.02)\end{array}$ & $\begin{array}{l}2.42 * * * \\
(1.48-3.95)\end{array}$ \\
\hline
\end{tabular}

In both Bivariate and Multivariate logistic regression analysis age, fast food intake, Alcohol consumption, less physical activity, increased body mass index, significantly associated with high blood pressure.

\section{DISCUSSION}

The present school-based study on risk factors of non-communicable diseases among students has documented a high risk factor profile for non-communicable diseases among students.

Table 3 found about one fifth of students (20.8\%) were found to have high blood pressure and $7.1 \%$ of students were suffering from hypertension. High blood pressure among boys and girls were 19.9\% and $22.1 \%$ were respectively.

In similar school based crosssectional study Khan M I, et al. ${ }^{[6]}$ (2010) $9.78 \%$ were found to be hypertensive, Sharma, et al. ${ }^{\text {[7] }}$ (2010) hypertension was identified in 5.9\% children and pre hypertension in $12.3 \%$, Kumar D. ${ }^{[8]}$ (2011) the prevalence of elevated blood pressure was among students urban 25(10\%) vs rural 23(9.2\%), Buch $\mathrm{N}$ et.al. [9] (2011) total prevalence of hypertension was $6.48 \%$, Anisa M et al. ${ }^{[10]}$ (2011) hypertension with 
overall prevalence of $9.4 \%$ children, Shah SS et al. [11] (2013) 20.09\% were hypertensive, Sundar JS et al. ${ }^{[12]}$ (2013) the prevalence of adolescent hypertension was 21.5\%, Patil RR et al. ${ }^{[13]}$ (2014) overall, prevalence of hypertension was 3.0\%, Patel YR. ${ }^{[14]}$ (2015) the overall prevalence of pre hypertension was $11.2 \%$ and that for hypertension was $7.4 \%$, Madhavikutty Amma GD et al. [15] (2015) overall prevalence of pre hypertension and hypertension was $24.5 \%$ and $0.6 \%$ respectively.

Table 4 found ages group-wise $3.8 \%$, 9.5\% and $7 \%$ students of $10-12$ years, 13-15 years and 16-18 years were hypertensive. In similar school based crosssectional study Khan M I, et al. ${ }^{[6]}$ (2010) the highest prevalence was found at 19 years of age (21.7 \%), Srinivas HA et al. ${ }^{[14]}$ (2014) in the study, hypertension was predominant in the age group of 13 yrs (12.2\%).

Table 5 founds in Bivariate analysis age $>15$ years (median) $(\mathrm{OR}=2.11)$, fast food intake ( $>3$ times/week) $(\mathrm{OR}=1.66)$, Alcohol consumption $(\mathrm{OR}=2.22)$, less physical activity $(\mathrm{OR}=1.54)$, increased body mass index $(\mathrm{OR}=2.53)$, significantly associated with high blood pressure. In Multivariate analysis age $(\mathrm{AOR}=2.25)$, fast food intake $(\mathrm{AOR}=1.50), \quad$ Alcohol consumption $(\mathrm{OR}=2.23)$, less physical activity $(\mathrm{AOR}=1.71)$, increased body mass index $(\mathrm{AOR}=2.42)$ remains significant predictor. In similar study Khan M I, et al [6] (2010) found no association between hypertension and other risk factors like added salt, junk food and the socioeconomic class, Singh A K et al. ${ }^{[16]}$ (2006) found the risk factors associated with blood pressure were sex, adding extra table salt, being obese and smoking, Kumar D. ${ }^{[8]}$ (2011) found overweight was a risk factor for elevated blood pressure in the study group (Odds ratio $=3.43$ ), Shah SS et al. [11] (2013) found obesity strongly associated with hypertension in children, Sundar JS et al . ${ }^{[12]}$ (2013) found there was significant $(\mathrm{p}<0.05)$ effect on blood pressure by gender, body mass index and decreased physical activity (OR $>3)$, Madhavikuttyamma GD et al. ${ }^{[15]}$ (2015) found male sex (AOR-1.67), overweight/obese (AOR-5.7 95), low fruit consumption (AOR-2.02) were the significant risk factors for pre hypertension and hypertension.

The cross-sectional study was conducted in a single school of Tarakeswar Block of Hooghly District. Results are not representative of the district or the block.

Quality of collected information through questionnaire on dietary behaviour of participants such as frequency of intake of fruits and vegetables, fast food intake, intake of extra salt intake with food etc. had some inherent limitation due to recall bias which is very much dependent on age of the participant, gender, intelligence, mood, attention, and consistency of eating pattern etc.

As information regarding health related practices were self-reported by the participants there is a possibility that sensitive and socially undesirable responses like smoking habit, alcohol intake etc., might have been underreported though the assurance made by the researcher regarding maintenance of anonymity and confidentiality of the data.

\section{CONCLUSION}

It is a common practice that we push in the problems of early risk factors of the children and adolescents under the carpet and we wait and watch for the emergence of diseases in the adults when it is too late for primary or even sometimes secondary prevention. Awareness level would also provide a baseline upon which, heath promotional strategies can be developed. Detecting the risk factors of high blood pressure prevalent in the population is of utmost importance to achieve a healthy population.

Screening for high blood pressure and their risk factors should be regularly conducted at school level. Students with high risk profile will need regular monitoring and counseling services. Local 
Health Workers supported by trained teachers may carry out these activities as an extension of School Health Programme under National health mission (NHM).

Early detection of risk factors of high blood pressure and their monitoring / referral can be done by Health workers, ASHA and AWWs, who can be trained to measure blood pressure by using digital sphygmomanometer.

Formulation and dissemination of need--based, culturally acceptable and age appropriate scientific messages for school students should be conducted more proactively. National Program for Prevention and Control of Cancer, Diabetes, And Cardiovascular Diseases and Stoke should consider school-based interventions with due priority.

\section{ACKNOWLEDGEMENT}

I would like to acknowledge with all my gratitude, regards and sincerity the help of the persons concerned without whom this research work would not have seen thelight of the day.

1. Dr. R.N. Chaudhuri, Director, All India Institute of Hygiene and Public Health--for allowing me to complete this research work as a part of the course of M.D. in Community Medicine in his institution.

2. Dr. Lina Bandyopadhyay, assistant professor, Department of Preventive and Social Medicine, All India Institute of Hygiene and Public Health, Kolkata, for her constant help, guidance, supervision, valuable suggestions and whole hearted encouragement during the study.

3. Dr. Bobby Paul, assistant professor, Department of Preventive and Social Medicine, All India Institute of Hygiene and Public Health, Kolkata, for her constant help, guidance, supervision, valuable suggestions and whole hearted encouragement during the study.

4. Dr. Indranil Saha, Associate Professor, Department Of Community Medicine IQ City Medical College, Durgapur, West Bengal for his valuable suggestions.
5. All the school teachers and the member of managing committee of the school of study for their sincere cooperation.

6. I am also deeply indebted to all those study participants for their sincere cooperation without which it would not have been possible for me to complete the study.

I am willing to declare that all the expenses for this research work were done by me and there was no sponsorship from anywhere.

\section{Conflict of Interest: None}

\section{Source of Funding: None}

\section{Ethical Approval: Approved}

\section{REFERENCES}

1. Bonita R, de Courten M, Dwyer T, Jamrozik $\mathrm{K}$, Winkelmann R. Surveillance of risk factors for non-communicable diseases: the WHO STEPS wise approach. Geneva: World Health Organization; 2002 http://apps.who.int/iris/bitstream/10665/671 78/1/WHO_NMH_CCS_01.01_Rev.1.pdf[L ast accessed on 2015 Sep 30]

2. World Health Organization. Global Schoolbased Student Health Survey (GSHS): 2006 India, central board of secondary education (CBSE) GSHS questionnaire. http://www.who.int/chp/gshs/india/en/index. html. [Last accessed on 2015 Sep 30]

3. WHO: Growth reference 5-19 years 2007 http://www.who.int/growthref/who2007_bm i_for_age/en/[Last accessed on 2015 Sep 30]

4. The fourth report on the diagnosis, evaluation, and treatment of high blood pressure in children and adolescents. US department of health and human services national institutes of Health National Heart, Lung, and Blood Institute NIH Publication No. 05-5267 Originally printed September 1996 (96-3790) Revised May 2005 https://www.nhlbi.nih.gov/files/docs/resourc es/heart/hbp_ped.pdf[Last accessed on 2015 Sep 30]

5. The Seventh Report of the Joint National Committee on Prevention, Detection, Evaluation, and Treatment of High Blood Pressure (JNC 7). U.S. Department of Health and Human Services National 
Malay Kumar Das et.al. Prevalence and determinants of high blood pressure among adolescents: a school based study in rural area of Hooghly district, West Bengal.

Institute of Health National Heart, Lung and Blood Institute National High Blood Pressure Education Program NIH Publication No. 03-5231. May 2003. https://www.nhlbi.nih.gov/files/docs/guideli nes/express.pdf[Last accessed on 2015 Sep 30]

6. Khan M I, et al. A Study Of The Risk Factors And The Prevalence Of Hypertension In The Adolescent School Boys Of Ahmadabad City. Journal of Clinical and Diagnostic Research. 2010 December ; $\quad$ 4):3348 3354 http://www.jcdr.net/articles/PDF/1092/1078 _E(C)_F(J)_R(S)_p.pdf[Last accessed on 2015 Sep 30]

7. Sharma, et al. Prevalence of Hypertension Among Schoolchildren in Shimla. Indian Pediatrics Volume 47 October 17, 2010. Http://indianpediatrics.net/oct2010/873.pdf[ Last accessed on 2015 Sep 30]

8. Dinesh Kumar. A comparison of the risk factors for the coronary artery diseases among the rural and urban male high school students in Vellore district, Tamilnadu: A school based cross sectional study. $\mathrm{He}$ a $\mathrm{lt}$ h l i n e ISSN 2229-337X Volume 2 Issue 2 July-December 2011. www.iapsmgc.org/index_pdf/41.pdf[Last accessed on 2015 Sep 30]

9. Buch N, Goyal JP, Kumar N, Parmar I, Shah VB, Charan J. Prevalence of hypertension in school going children of Surat city, Western India. J Cardiovasc Dis Res 2011; 2:22832

http://www.ncbi.nlm.nih.gov/pmc/articles/P MC3224443/[Last accessed on 2015 Sep 30]

10. Anisa M. Durrani, Wasim Fatima. Determinants of blood pressure distribution in school children. European Journal of Public Health, Vol. 22, No. 3, 373377(doi:10.1093/eurpub/ckr036 Advance Access published on 7 April 2011). http://eurpub.oxfordjournals.org/content/22/ 3/369[Last accessed on 2015 Sep 30]
11. Shah SS, Dave BR, Sharma AA, Desai AR. Prevalence of Hypertension and Association of Obesity with Hypertension in School Going Children of Surat City, Western India. Online J Health Allied Scs. 2013; 12(2):5.

12. Sundar JS, Adaikalam JMS, Parameswari S, Valarmarthi S, Kalpana S, et al. (2013) Prevalence and Determinants of Hypertension among Urban School Children in the Age Group of 13- 17 Years in, Chennai, Tamilnadu. Epidemiol 3: 130. Doi:10.4172/2161-1165.1000130

13. Patil RR, Garg BS. Prevalence of hypertension and variation in blood pressure among school children in rural area of Wardha. Indian J Public Health 2014; 58:78-83.

Http://www.ncbi.nlm.nih.gov/pubmed/2482 0979[Last accessed on 2015 Sep 30]

14. Patel YR .Blood Pressure Survey in Residential School Children. Indian Journal Of Applied Research Volume: 5 | Issue: 6 | June 2015

15. Madhavikuttyamma GD, Vasudevan B, Akshayakumar S. Prevalence and determinants of prehypertension and hypertension among adolescents: a school based study in a rural area of Kerala, India. Int J Res Med Sci 2015; 3:58-64

16. Sing A.K., Maheshware A., Sharma N. And Anand K. (2006): Life-Style Associated Risk Factors in Adolescents; Indian $\mathrm{J}$ of Pediatrics, 73: 901-906. www.ncbi.nlm.nih.gov/pubmed/17090902[ Last accessed on 2015 Sep 30]

How to cite this article: Das MK, Sinha R, Dasgupta A et.al. Prevalence and determinants of high blood pressure among adolescents: a school based study in rural area of Hooghly district, West Bengal. International Journal of Research and Review. 2021; 8(11): 205-210. DOI: https://doi.org/10.52403/ijrr.20211127 